\title{
Epstein-Barr Virus Negative
}

National Cancer Institute

\section{Source}

National Cancer Institute. Epstein-Barr Virus Negative. NCI Thesaurus. Code C141321.

An indication that Epstein-Barr virus has not been detected in a sample. 